\title{
MANGANÊS NO BRASIL: DESCOBERTA, EXTRAÇÃO, CONSUMO E COMERCIALIZAÇÃO NUMA PERSPECTIVA HISTÓRICA
}

\author{
Júlio Carlos Afonso*,a, \\ a'Departamento de Química Analítica, Instituto de Química, Universidade Federal do Rio de Janeiro, 21941-909 Rio de Janeiro \\ - RJ, Brasil
}

Recebido em 10/06/2019; aceito em 31/07/2019; publicado na web em 04/11/2019

\begin{abstract}
MANGANESE IN BRAZIL: DISCOVERY, EXTRACTION, CONSUMPTION AND MARKETING FROM A HISTORICAL PERSPECTIVE. This work describes the occurrence and the economic importance of manganese in Brazil, covering a period of almost 130 years. After the gold cycle, manganese ores became the most important mineral commodity of Brazil's export agenda until 1945. Brazil has one of the largest world reserves and has been among the world's largest producers of manganese ore for over a century. The influence of international scenario on the manganese market affected its trade balance throughout the twentieth century. The Brazilian manganese ore production was strongly stimulated by external events (such as the I and II World Wars) and the development of the US and the European steel industries in the early $\mathrm{XX}^{\mathrm{th}}$ century. However, internal consumption increased as the Brazilian steel industry developed. The chief use of manganese in Brazil and in the world is in the steel production. Nonmetallurgical uses include battery cathodes, fertilizers, animal feed, water treatment, analytical chemistry (permanganometry), pigments, cosmetics and glasses. The perspectives for manganese in Brazil in the future are encouraging, but it is necessary to search for new deposits and develop processing of tailings and low grade ores.
\end{abstract}

Keywords: manganese; manganese ores; manganese in Brazil; steel; uses of manganese.

\section{O ELEMENTO MANGANÊS}

O manganês é um elemento pertencente ao grupo 7 da Tabela Periódica, e consiste de uma única espécie atômica, ${ }^{55} \mathrm{Mn}$. É o $12^{\circ}$ elemento mais abundante na crosta terrestre $\left(\sim 1 \mathrm{~g} \mathrm{~kg}^{-1}\right)$. Na água do mar, a concentração é da ordem de $10 \mathrm{mg} \mathrm{L}^{-1} .^{1}$

Ele um metal cinza escuro, duro e quebradiço. Funde a $1247^{\circ} \mathrm{C}$ e entra em ebulição a $2061{ }^{\circ} \mathrm{C}$. ${ }^{1}$ Sua massa específica é $7,43 \mathrm{~g} \mathrm{~cm}^{-3}$, semelhante à do aço inoxidável comum $\left(7,86 \mathrm{~g} \mathrm{~cm}^{-3}\right)$ e do ferro $\left(7,874 \mathrm{~g} \mathrm{~cm}^{-3}\right){ }^{1}$

Antes de o elemento ser descoberto, seus óxidos já eram empregados desde a Idade da Pedra, como atestam, por exemplo, algumas pinturas rupestres das grutas de Lascaux (França). ${ }^{2}$ Vidreiros egípcios e romanos os utilizavam tanto para remover como para introduzir coloração em vidros, ${ }^{2,3}$ bem como em toda uma variedade de experimentos feitos por alquimistas e químicos. ${ }^{4}$ Por exemplo, Carl Wilhelm Scheele (1742-1786) descobriu o cloro graças à reação do $\mathrm{MnO}_{2}$ com uma mistura de ácido sulfúrico $\left(\mathrm{H}_{2} \mathrm{SO}_{4}\right)$ e cloreto de sódio $(\mathrm{NaCl})$. Isso levou à primeira grande aplicação industrial do manganês: a manufatura de cloro e de soluções alvejantes (solução aquosa de $\left.\mathrm{Cl}_{2}\right){ }^{1,4}$ Scheele e outros cientistas de seu tempo acreditavam que aqueles óxidos continham um novo elemento. ${ }^{4} \mathrm{~A}$ primeira evidência data de 1770, quando o austríaco Ignatius Gottfried Kaim (1746-1778), em sua dissertação intitulada De metallis dubiis, descreveu a reação do $\mathrm{MnO}_{2}$ com carbono, produzindo um metal quebradiço. Esse trabalho teve pouca repercussão na época. ${ }^{4} \mathrm{Em}$ 1774, Johan Gottlieb Gahn (1745-1818) repetiu essencialmente o processo de Kaim, mas descreveu melhor o experimento e seus resultados. Em um cadinho, ele colocou $\mathrm{MnO}_{2}$, óleo e carvão, cobriu o conjunto e o aqueceu. Ao abrir o cadinho, ele viu uma massa metálica. Tratava-se do manganês. ${ }^{1}$

Quimicamente o metal é bastante reativo. Na forma de pó, é lentamente oxidado pelo oxigênio atmosférico, chegando mesmo a ser pirofórico. Na forma maciça, o manganês somente reage com $\mathrm{O}_{2}$ quando aquecido. Decompõe lentamente a água à temperatura ambiente e mais rapidamente a quente. É facilmente dissolvido em soluções diluídas de ácidos (inclusive não oxidantes), formando íons $\mathrm{Mn}^{2+}$. Reage vigorosamente com flúor e cloro. Mediante aquecimento, reage com enxofre, fósforo, carbono, bromo, iodo, silício, boro, selênio, telúrio e nitrogênio. A química do manganês é notável por ser um elemento que apresenta 11 números de oxidação (alguns bastante incomuns), de -3 até +7 . O mais estável deles é o +2 , correspondendo ao íon $\mathrm{Mn}^{2+}$.

Afora sua importância econômica, a ser detalhada mais adiante, cabe destacar que o manganês tem papel importante em todos os organismos animais e vegetais. ${ }^{1,5,6} \mathrm{~A}$ forma utilizável biologicamente é o $\mathrm{Mn}^{2+}$. Nos vegetais, ele participa das enzimas fosfotransferases (que atuam no crescimento das plantas) e no processo de fotossíntese (etapa de foto-oxidação da água, com liberação de $\mathrm{O}_{2}$ pelos cloroplastos). O elemento é o $3^{\circ}$ metal de transição mais importante em nossa dieta (após ferro e zinco). A Agência Nacional de Vigilância Sanitária (ANVISA) recomenda uma ingestão diária (IDR) de 5 mg. As principais fontes são cereais integrais, legumes, verduras e frutas. Em média, um organismo adulto contém $12 \mathrm{mg}$, concentrados no fígado e rins. Os sintomas da deficiência de manganês incluem: perda de peso, fadiga, redução da fertilidade, dermatite, perturbação no metabolismo de ossos e cartilagens, alteração da síntese de insulina, redução da taxa de colesterol no sangue, intensificação de reações alérgicas e inflamatórias e malformações fetais. ${ }^{7} \mathrm{O}$ elemento aparece como cofator de uma grande variedade de enzimas (oxidorredutases, transferases, hidrolases, isomerases etc.). No organismo humano, a superóxido dismutase (SOD) é responsável pela metabolização dos radicais livres nas mitocôndrias, e a arginase (produzida no fígado) participa do ciclo da uréia $\left[\mathrm{CO}\left(\mathrm{NH}_{2}\right)_{2}\right]$, meio de eliminação do íon amônio $\left(\mathrm{NH}_{4}{ }^{+}\right)$oriundo do grupo $\mathrm{NH}_{2}$ de proteínas. ${ }^{1} \mathrm{O}$ manganês é essencial na síntese do colesterol e da dopamina (neurotransmissor). ${ }^{7}$ 


\section{OCORRÊNCIA NA NATUREZA}

Dos mais de 100 minerais de manganês hoje conhecidos, poucos são empregados na obtenção do elemento. ${ }^{2,8}$ Os depósitos são abundantes, mas distribuem-se irregularmente no espaço e no tempo geológico. ${ }^{8}$ Destacam-se os óxidos $\mathrm{MnO}_{2}$ (o mais importante), $\mathrm{Mn}_{3} \mathrm{O}_{4}$, $\mathrm{Mn}_{2} \mathrm{O}_{3}, \mathrm{MnOOH}$, e o carbonato $\mathrm{MnCO}_{3}$. A Tabela 1 apresenta os principais minerais de manganês. A pirolusita é o mineral de maior importância comercial. No fundo dos oceanos (inclusive na costa brasileira), há nódulos metálicos contendo manganês, com uma reserva estimada em $5 \times 10^{11}$ t do elemento. ${ }^{3,8}$

As reservas mundiais de manganês em 2014 foram estimadas em 625 milhões de $\mathrm{t}$ de minério ROM (run of mine), ${ }^{2,9}$ valor que atingiu 708,1 milhões em 2016. ${ }^{10}$ As maiores reservas estão situadas na África do Sul, com 200 milhões de t (28,2\% da reserva mundial), seguidas pelas reservas da Ucrânia, com 140 milhões de t (19,8\%); Brasil, com 136,5 milhões de t (19,3\%); Austrália, com 91 milhões de t (12,9\%); Índia, com 52 milhões de t (7,3\%); China, com 43 milhões de $\mathrm{t}(6,1 \%)$; Gabão, com 22 milhões de $\mathrm{t}(3,1 \%)$, e Gana, com 13 milhões de $\mathrm{t}(1,8 \%)$. Esses países detêm cerca de $98,5 \%$ do total das reservas mundiais conhecidas na atualidade. ${ }^{10} \mathrm{O}$ manganês é um dos bens minerais cujas reservas e produção no Brasil são de elevada expressão no cenário internacional. ${ }^{11,12}$

Apesar de sua abundância na crosta terrestre, o manganês é tido como um elemento estratégico em função de seu largo emprego e sua distribuição geográfica: o traço mais marcante do mercado internacional de manganês é a distinção entre os principais países produtores e os principais países consumidores, posto que esses últimos não possuem grandes depósitos em seus territórios (Estados Unidos, Japão, Alemanha, Canadá, Itália, Bélgica, França e Inglaterra),$^{8} \mathrm{o}$ que indica que possuem dependência do fornecimento de manganês do estrangeiro para suas indústrias siderúrgicas, sendo um mercado bastante atrativo para países de economia emergente como o Brasil. ${ }^{13}$

Tabela 1. Principais minerais de manganês ${ }^{2,8}$

\begin{tabular}{|c|c|c|}
\hline Mineral & Fórmula química & $\begin{array}{c}\text { Teor típico de } \\
\text { manganês }(\% \mathrm{~m} / \mathrm{m})\end{array}$ \\
\hline Bementita & $\mathrm{Mn}_{8} \mathrm{Si}_{6} \mathrm{O}_{15}(\mathrm{OH})_{10}$ & 43,2 \\
\hline Braunita & $\left(\mathrm{Mn}^{2+}\right)\left(\mathrm{Mn}^{3+}\right)_{6} \mathrm{SiO}_{12}$ & 66,6 \\
\hline Psilomelano & $\mathrm{Ba}_{2} \mathrm{Mn}_{5} \mathrm{O}_{10} \cdot \mathrm{H}_{2} \mathrm{O}$ & $45-60$ \\
\hline Criptomelano & $\mathrm{K}\left(\mathrm{Mn}^{4+}, \mathrm{Mn}^{2+}\right)_{8} \mathrm{O}_{16}$ & $54-59$ \\
\hline Espessartita & $\mathrm{Mn}_{3} \mathrm{Al}_{2}\left(\mathrm{SiO}_{4}\right)_{3}$ & 33,3 \\
\hline Hausmanita & $\mathrm{Mn}_{3} \mathrm{O}_{4}$ & 72 \\
\hline Jacobsita & $\mathrm{Fe}_{2} \mathrm{MnO}_{4}$ & 23,8 \\
\hline Litioforita & $(\mathrm{Li}, \mathrm{Fe}, \mathrm{Al}) \mathrm{MnO}_{3} \cdot \mathrm{H}_{2} \mathrm{O}$ & 30,4 \\
\hline Manganita & $\mathrm{MnO}(\mathrm{OH})$ & 62,5 \\
\hline Pirolusita & $\beta-\mathrm{MnO}_{2}$ & 63,2 \\
\hline Piroxmangita & $\left(\mathrm{Mn}^{2+}\right)_{\mathrm{x}}\left(\mathrm{Fe}^{2+}\right)_{1-\mathrm{x}} \mathrm{SiO}_{3}$ & 38,3 \\
\hline Rodocrosita & $\mathrm{MnCO}_{3}$ & 47,6 \\
\hline Rodonita & $\left(\mathrm{Mn}^{2+}, \mathrm{Fe}^{2+}, \mathrm{Ca}^{2+}\right) \mathrm{SiO}_{3}$ & 38,3 \\
\hline Tefroíta & $\mathrm{Mn}_{2} \mathrm{SiO}_{4}$ & 54,3 \\
\hline
\end{tabular}

Em 1918, o U.S. Bureau of Mines ${ }^{14}$ classificou os minérios de manganês em três categorias: minério "alto" ou minério de manganês, com $35 \% \mathrm{~m} / \mathrm{m}$ de manganês no mínimo; minério "médio" ou de manganês ferruginoso, com 10-25\% m/m de manganês; minério "baixo" ou de ferro manganífero, com 5-10\% em massa de manganês. O valor de mercado decai rapidamente nessa ordem: “Ao passo que o minério alto tem sempre compradores a bom preço, o de teor médio é vendido com menos facilidade e o minério baixo só encontra mercado em situações excepcionais da indústria metalúrgica, raramente dando lucro compensador." 15

Os principais depósitos do Brasil hoje conhecidos (Figura 1) compreendem a Mina do Igarapé Azul, localizada na Província Mineral de Carajás (Parauapebas, PA), a Serra do Navio, no estado do Amapá (Figura 2), e o depósito de Urucum, no Mato Grosso do Sul (Figura 3). ${ }^{2}$ O Morro da Mina é considerado o depósito de maior importância em Minas Gerais, situado na província mineral do Quadrilátero Ferrífero, próximo à cidade de Conselheiro Lafaiete. ${ }^{2} \mathrm{O}$ minério de manganês hoje produzido no país se enquadra nas categorias "alto" e "médio". ${ }^{10}$ No estado de Goiás há algumas ocorrências de manganês, geralmente de pequeno porte, mas de teor elevado, tendo algumas delas já sido exploradas. ${ }^{8,16}$ Outras ocorrências ${ }^{6,12,17}$ foram relatadas nos estados de São Paulo, Amazonas, Ceará, Maranhão, Santa Catarina, Rondônia e Espírito Santo (Figura 1).

O manganês no Brasil é principalmente encontrado na forma de óxidos, mas também existem depósitos de rodocrosita (Figura 4), espessarita, tefroíta e rodonita (Figura 5) em Conselheiro Lafaiete $(\mathrm{MG})^{18}$ e Urandi (BA). ${ }^{19}$

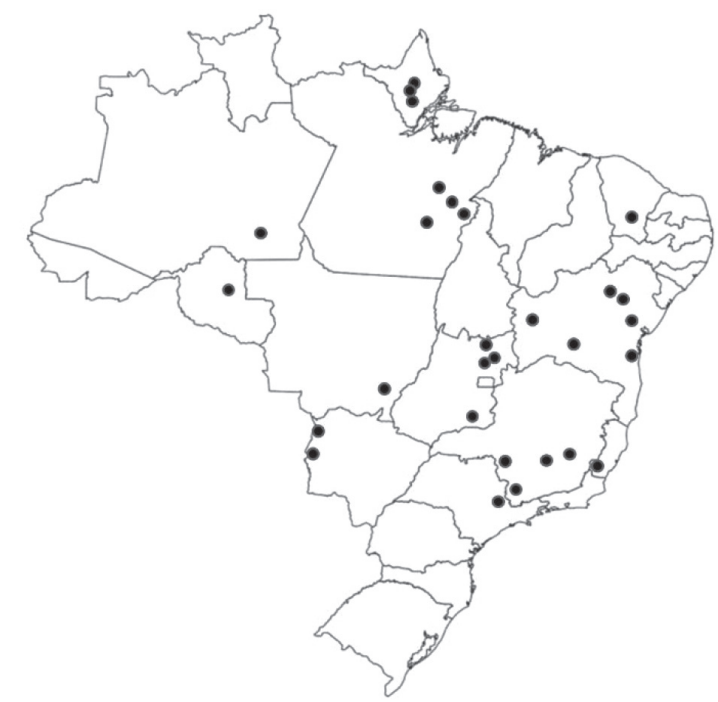

Figura 1. Localização das principais reservas de manganês em território nacional. Adaptado a partir das informações das referências 10, 11, 12 e 16

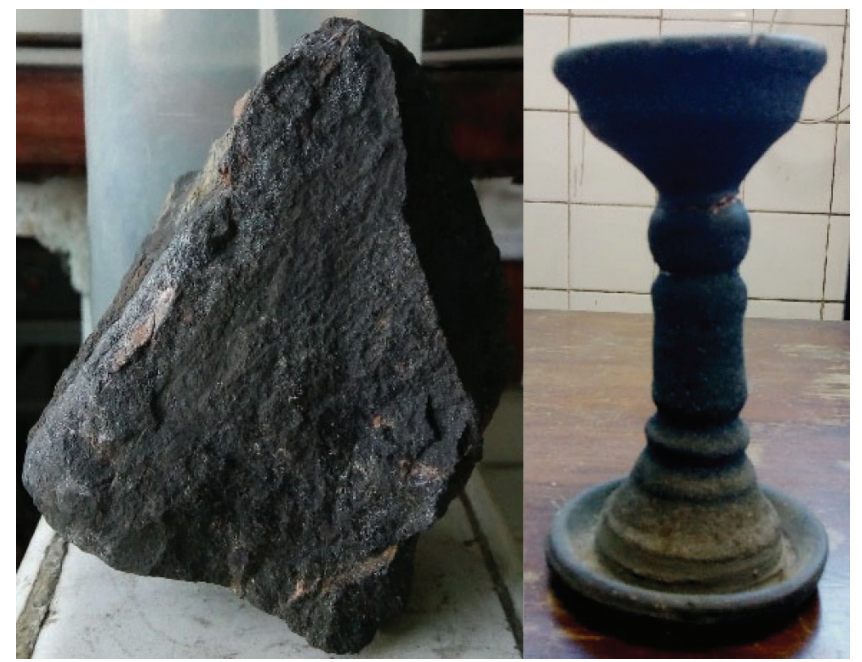

Figura 2. Esquerda: Amostra de pirolusita $\left(\beta-\mathrm{MnO}_{2}\right)$ proveniente da Serra do Navio (AP). Direita: peça em argila revestida por pirolusita da Serra do Navio. Imagens do autor 


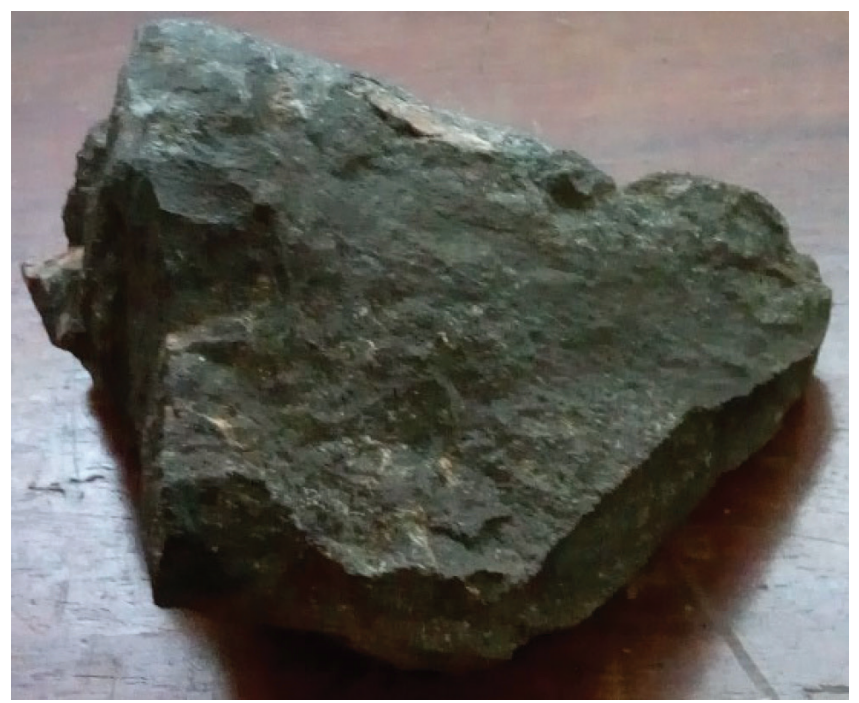

Figura 3. Amostra de pirolusita $\left(\beta-\mathrm{MnO}_{2}\right)$ proveniente de Urucum $(\mathrm{MS})$. Imagem do autor

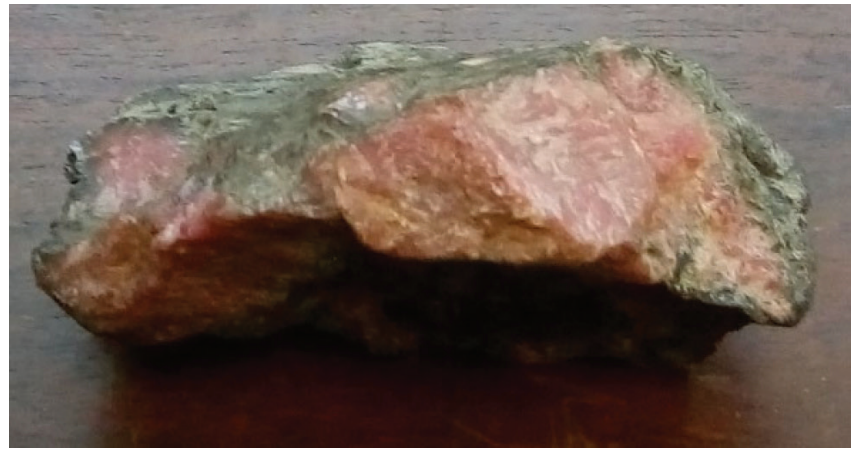

Figura 4. Amostra de rodocrosita $\left(\mathrm{MnCO}_{3}\right)$ de Conselheiro Lafaiete $(\mathrm{MG})$. Imagem do autor

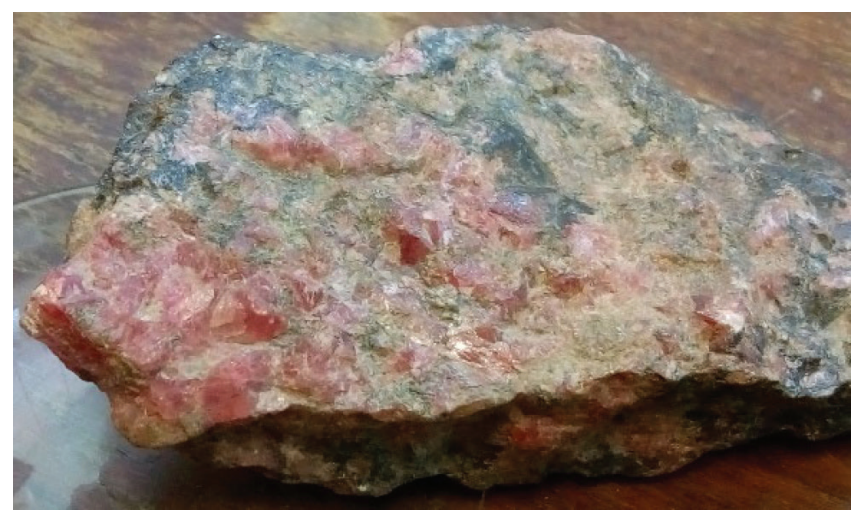

Figura 5. Amostra de rodonita $\left(\mathrm{MnSiO}_{3}\right)$ de Conselheiro Lafaiete $(M G)$. Imagem do autor

\section{EMPREGOS DO MANGANÊS}

O manganês é um elemento muito presente na sociedade moderna. Seu emprego principal desde meados do século XIX é no setor siderúrgico - produção de ligas metálicas. ${ }^{2,8}$ As ferro-ligas, compostas pelo ferro com adição de elementos metálicos como manganês, silício, níquel e nióbio, entre outros, são importantes insumos siderúrgicos. A razão que explica tão amplo emprego em siderurgia é que o manganês, na forma de minério, liga com ferro, escória de refino ou mesmo sucata, atua como agente dessulfurante e desoxidante do aço produzido ${ }^{8,20} \mathrm{O}$ desenvolvimento do conversor de Henry Bessemer
(1813-1898), em 1856, permitiu a produção de aço em grande escala a partir de ferro gusa e com custos menores que os processos que usavam cadinhos, alavancando com isso o emprego do manganês na siderurgia. ${ }^{21}$ Hoje, de 85 a $95 \%$ do manganês produzido no mundo é empregado na produção de ligas. ${ }^{2,8,11} \mathrm{O}$ fato mais importante da economia mundial do manganês é que não se conhece uma alternativa economicamente viável a ele como insumo siderúrgico.$^{22} \mathrm{O}$ minério "alto" permite obter ligas ferro-manganês de alta qualidade, podendo mesmo ser diretamente inserido no processo produtivo; o minério "baixo" só se presta para ajustar o balanço da proporção $\mathrm{Mn} / \mathrm{Fe}$ na liga ou à produção dessas ligas de baixa qualidade. ${ }^{23}$

O manganês é usado ainda em combinação com outros metais, além do ferro, na produção de ligas: cobre, zinco, alumínio, estanho e chumbo. ${ }^{2}$ Ligas com antimônio ou alumínio e cobre (ligas de Heusler) têm propriedades ferromagnéticas, embora nenhum desses elementos tenha essa propriedade. A mangarina $(84 \% \mathrm{Cu}, 12 \% \mathrm{Mn}, 4 \% \mathrm{Ni})$ é usada em contatos elétricos.

Após beneficiamento adequado, o óxido $\mathrm{MnO}_{2}$ é empregado como catodo de pilhas $\mathrm{Zn}-\mathrm{C}$ (Leclanché e alcalinas), ${ }^{2,8}$ no qual atua como despolarizador e receptor de elétrons liberados no anodo. ${ }^{24}$ Novas e promissoras aplicações do manganês no setor de energia portátil estão nas pilhas de uso único $\mathrm{Li} / \mathrm{MnO}_{2},{ }^{25} \mathrm{e}$ em especial nas baterias de íon-lítio, onde substitui parte do cobalto no catodo $\mathrm{LiCoO}_{2} \cdot{ }^{26}$

O dióxido é utilizado como pigmento cerâmico (fabricação de telhas, tijolos e objetos de tonalidade negra, acinzentada e marrom, de belo efeito decorativo), ${ }^{8}$ na manufatura de tintas (acelerador da formação de película da tinta e do verniz) e vidros de coloração verde, rósea ou púrpura.

$\mathrm{O}$ dióxido é ainda a matéria-prima para obtenção do $\mathrm{KMnO}_{4}$ ( 40-50 mil t produzidas por ano entre 1993 e 2012), ${ }^{27}$ poderoso agente oxidante, utilizado em química analítica (permanganometria), e industrialmente na produção do ácido ascórbico (vitamina $\mathrm{C}$ ), da niacina (ácido nicotínico) e da sacarina. No passado, ele foi muito usado como desinfetante doméstico, mas esse emprego foi abandonado por ser agressivo à pele. Contudo, ainda se utiliza (1 parte de $\mathrm{KMnO}_{4}$ em 40.000 de água) para tratar a pele de pessoas com varicela (catapora), visando aliviar a coceira. O sulfato $\mathrm{MnSO}_{4}$ é usado na produção de fertilizantes, ${ }^{8}$ na alimentação animal e ainda em suplementos vitamínico-minerais. O etileno(bis-ditiocarbamato) de manganês e zinco, fungicida e acaricida, é usado em mais de 30 culturas como verduras e árvores frutíferas. ${ }^{28}$

As aplicações do manganês e de seus compostos exigem tanto um grau de pureza mais elevado como um teor de impurezas minimizado. Por exemplo, para o emprego em pilhas alcalinas, o $\mathrm{MnO}_{2}$ não deve conter cobre, níquel, cobalto e arsênio, e pode apresentar, no máximo, $4 \%$ em massa de ferro. ${ }^{3}$ Tais exigências resultaram no incremento da complexidade do processo de beneficiamento dos minérios. Como a qualidade dos depósitos de manganês varia muito de uma jazida a outra, soluções específicas para cada caso devem ser pesquisadas e desenvolvidas. ${ }^{3}$

\section{PRODUÇÃO MUNDIAL DE MANGANÊS}

O manganês é hoje o quarto metal mais utilizado no mundo, depois de ferro, cobre e alumínio., ${ }^{911}$ De acordo com o International Manganese Institute, a produção mundial de minério de manganês em 2017 atingiu 19 milhões de t (17,7 milhões de t em 2014), ${ }^{9} \mathrm{o}$ que representa um aumento de $25 \%$ em relação à produção no ano de 2016. ${ }^{2}$ Segundo o Anuário Mineral Brasileiro do Departamento Nacional de Produção Mineral (DNPM), a produção brasileira de minério de manganês em 2015 atingiu cerca de 4,4 milhões de t, com teor médio de $35,73 \% \mathrm{~m} / \mathrm{m}$ do elemento. ${ }^{2}$ A produção nacional é dominada por três empresas: VALE (47,65\% em 2016), com 
lavras em Morro da Mina (Conselheiro Lafaiete, Minas Gerais) e na mina do Igarapé Azul (Parauapebas, Pará), hoje a maior mina em atividade no país, ${ }^{2,11}$ onde também opera a principal usina de beneficiamento de minério de manganês; Mineração Corumbaense Reunida (23,93\%), que explora a mina de Urucum (Corumbá, Mato Grosso do Sul); Mineração Buritirama (23,02\%), com lavra na Serra do Buritirama (Marabá, Pará). ${ }^{10,13}$ Quatro outras empresas completam o quadro de produção: ${ }^{10}$ Brasil Manganês Corporation Mineração S.A. (Rondônia); Recursos Minerais do Brasil (Pará); Manganês Congonhal Ltda. (Minas Gerais); Ferlig Ferro Liga Ltda (Minas Gerais). O estado do Pará respondeu por $73 \%$ da produção brasileira em 2017, seguido de Mato Grosso do Sul (21\%), Minas Gerais (3\%), Rondônia ( $2 \%$ ) e Mato Grosso, Goiás e Bahia ( $1 \%$ do total). ${ }^{2}$

Os dados mais recentes do Ministério da Indústria, Comércio Exterior e Serviços (MDIC) ${ }^{29}$ indicam que as exportações em 2017 representaram uma elevação significativa na demanda por minério de manganês, em relação aos anos anteriores. O comércio movimentou um total superior a US\$ 365 milhões, correspondente a 2,683 milhões de $\mathrm{t}$ de minério de manganês e seus concentrados, o que representou um incremento de $81 \%$ em relação a 2016. A maior parte das exportações foi destinada à China (67\%), Argentina (12\%), Uruguai (12\%) e Ucrânia (3\%). As exportações para outros países incluem Noruega, Coréia do Sul, Índia e México. ${ }^{10}$ Em comparação a anos anteriores, a produção de 2017 está no patamar da registrada em 2012 (2,796 milhões de t), 2013 (2,833 milhões de t) e 2014 (2,723 milhões de $\mathrm{t}){ }^{9}$

Em 2016, 77\% da receita auferida com a exportação de bens minerais correspondia a elementos metálicos. Destes, oito responderam por $98,7 \%$ (US\$ 78,9 bilhões): ferro $(63,4 \%)$, ouro $(16,2 \%)$, cobre $(7,6 \%)$, alumínio $(4,8 \%)$, níquel $(3,5 \%)$, manganês $(1,3 \%)$, estanho $(1,1 \%)$ e nióbio $(0,8 \%) .{ }^{10}$ Em 2012 , o manganês ocupou o oitavo lugar em termos de valor de produção entre as commodities minerais exportadas $(0,6 \%)$, a quarta colocação em $2014(0,8 \%)^{9}$ e a sexta posição em $2016(1,3 \%)$ e $2018(1,2 \%) .{ }^{30}$ Enquanto isso, o minério de ferro é largamente o líder, com 80,3\% em 2012, ${ }^{30} 87,7 \%$ em $2014,{ }^{9}$ 63,2\% em $2016^{10}$ e $64,2 \%$ em $2018 .{ }^{30}$ Enquanto nos últimos anos a produção de minério de manganês foi da ordem de 2,8-4,0 milhões de t/ano, a de minério de ferro se situa em torno de 400 milhões de t/ano, o que coloca nosso país entre os três maiores produtores mundiais dessa commodity. ${ }^{12}$

De acordo com o MDIC, as exportações de manganês e derivados alcançaram, em 2014, US\$ 328 milhões a preços free on board (FOB), valor inferior ao registrado em 2013 quando as exportações somaram US\$ 429 milhões. O minério de manganês liderou as vendas externas, que totalizaram US\$ 229 milhões FOB. Este valor é 13\% inferior ao registrado em 2013, tendo ocorrido baixa no preço internacional por tonelada na ordem de $22 \%$. Os produtos semimanufaturados atingiram US\$ 36 milhões FOB em exportações, com destaque para a liga ferro-silício-manganês ( $84 \%$ do total). Compostos de manganês apresentaram redução da ordem de $29 \%$ nos valores de exportação, caindo de US\$ 87 milhões em 2013 para US\$ 62 milhões em 2014. Os principais produtos desta classe são “óxidos, hidróxidos e peróxidos de manganês" (US\$ 54 milhões em 2014). O Brasil somente começou a produzir manganês metálico em 1989. Os principais compradores de manganês e derivados produzidos no Brasil em 2014 foram China (48\%), Argentina (17\%) e França (17\%) nos minérios, Argentina (47\%), Países Baixos (9\%) e Estados Unidos (7\%) nos semimanufaturados, e Alemanha (22\%), Chile (17\%) e Argentina (12\%) nos produtos químicos. ${ }^{9}$ Em 2016, os compradores foram: China (53,6\%), Argentina $(25,8 \%)$ e França $(13,4 \%)$ nos minérios; Argentina (35,6\%), Estados Unidos (17,2\%) e Itália (8,8\%), nos semimanufaturados; Estados Unidos $(49,1 \%)$, Alemanha $(21 \%)$ e China $(11,7 \%)$, nos produtos químicos. ${ }^{23}$
No Brasil, o consumo aparente de concentrado de manganês foi de 1,0 milhão de t em 2013, 725 mil t em 2014, 1,235 milhão de $t$ em 2015 e 1,2 milhão de $t$ em 2016. ${ }^{10,23}$ Essas oscilações refletem o aumento ou a queda das exportações e a produção de ligas ferro-manganês (por exemplo, houve pequeno decréscimo, da ordem de 2,5\% em 2014 - 303 mil t - contra 311 mil apontadas em 2013). Também foi registrado no período 2013/2014 decréscimo nas produções de concentrado e do teor de manganês contido. A demanda interna do concentrado de manganês continua com o mesmo perfil de anos anteriores: a indústria siderúrgica é a grande consumidora de minério de manganês, correspondendo a cerca de $85 \%$ do consumo interno, seguida pelo segmento de produção de pilhas $(8 \%)$ e produtos químicos $(5 \%)$. O consumo de manganês para a produção de pilhas tomou impulso no país a partir de 1951 com a instalação das primeiras fábricas de pilhas Leclanché, numa época em que o mercado nacional se restringia a poucos milhares de unidades anuais, basicamente para lanternas elétricas portáteis. Após o advento do transistor e de seu amplo uso em rádios portáteis e outros equipamentos de pequeno porte, a demanda de pilhas cresceu exponencialmente. Outros dois fabricantes se instalaram no país em 1968 e 1979. No final da década de 1970, o mercado nacional já consumia cerca de 1 bilhão de unidades por ano. As pilhas alcalinas começaram a ser produzidas no Brasil em 1978. ${ }^{31}$ A capacidade de produção instalada na década de 1980 já superava 1,2 bilhão de unidades/ano, que é o mercado brasileiro atualmente estimado segundo a Associação Brasileira da Indústria Elétrica e Eletrônica (ABINEE). ${ }^{32}$

Embora a balança comercial brasileira seja favorável em relação ao manganês, visto que há mais exportações em relação ao consumo interno, nota-se que a importação de concentrado de manganês e produtos semimanufaturados de países da África, como África do Sul e Gabão, é ainda perceptível. ${ }^{11,12}$ Isso ocorre devido a uma melhor qualidade quanto a impurezas e ao teor de manganês para aplicações específicas se comparado ao minério de manganês produzido no Brasil. ${ }^{11}$

\section{Quadro-resumo da produção brasileira de minério de manganês}

A Tabela 2 apresenta os dados de exportação de minério de manganês ao longo de 120 anos. ${ }^{13,33-35}$ Desde 1898 o Brasil figura entre os principais produtores mundiais de minério de manganês, mas sua posição oscilou muito em função do engajamento de outros países produtores em guerras (Rússia, Índia), da entrada de novos países nesse mercado (Gabão, Gana, Austrália) ou da ocorrência de desastres naturais. ${ }^{36} \mathrm{Na}$ segunda metade do século XX, o Brasil oscilou entre o $2^{\circ}$ e o $8^{\circ}$ produtor mundial. ${ }^{37}$ Desde 2000 ele se situa entre os cinco maiores produtores.

\section{HISTÓRICO: A SAGA DO MANGANÊS NO BRASIL}

\section{Os primeiros relatos}

Cita-se uma descrição da presença de manganês em Nazaré, na então Província da Bahia, em 1757, pelo prático José Thomaz do Nascimento, que identificou o que seria o dióxido $\mathrm{MnO}_{2} \cdot{ }^{38}$ Porém, com base em uma exploração geológica de caráter científico, as primeiras ocorrências de manganês no Brasil foram feitas por Wilhelm Ludwig von Eschwege (1777-1855), Barão de Eschwege, contratado pela Coroa Portuguesa para proceder ao estudo do potencial mineiro do Brasil. Em 1821, relatou que o manganês "era encontrado na estrada de Vila Rica a Barbacena, ao longo da cumiada que separa as bacias do Rio Grande e do Rio Doce". ${ }^{8}$ 
Em 1850, já havia um relatório dando conta da presença de manganês nas províncias de Minas Gerais (dezesseis localidades), Bahia (Nazaré) e Rio de Janeiro (Vassouras). ${ }^{39}$ Porém, nenhuma atividade exploradora foi mencionada.

Na então Província de Mato Grosso, já se conheciam depósitos de manganês no Morro do Urucum desde 1870, mas somente em 1909 é que os óxidos de manganês foram confirmados pelo geólogo Miguel Arrojado Ribeiro Lisboa (1872-1932). ${ }^{40}$ Em 1888, Henrique Eduardo Hargreaves, engenheiro, anunciou a existência de camadas de minérios de manganês ao longo do ramal de Ouro Preto da Estrada de Ferro Central do Brasil (EFCB). ${ }^{8}$

Por outro lado, muito antes de o manganês figurar como importante commodity de nossa pauta de exportações de bens minerais, ele já era citado em jornais, revistas e livros publicados no Brasil no século XIX. Essas citações se referiam a procedimentos que faziam apelo ao poder oxidante do $\mathrm{MnO}_{2}$, vendido comercialmente. Assim, em 1850, a mistura de ácido sulfúrico com cloreto de sódio e o dióxido servia à desinfecção de cômodos de residências, hospitais, asilos, orfanatos e prisões no combate às miasmas (emanações que supostamente provocariam contaminação por doenças infecciosas e epidêmicas). ${ }^{41,42}$
Era a chamada "água javela" ("água de cloro"), também usada como alvejante de tecidos brancos ${ }^{39}$ e na indústria de papel: ${ }^{43}$

$4 \mathrm{NaCl}+\mathrm{MnO}_{2}+2 \mathrm{H}_{2} \mathrm{SO}_{4} \rightarrow \mathrm{MnCl}_{2}+\mathrm{Cl}_{2}+2 \mathrm{Na}_{2} \mathrm{SO}_{4}+2 \mathrm{H}_{2} \mathrm{O}$

Da mesma forma, a obtenção de oxigênio e de cloro em laboratórios, e o emprego em cerâmicas, pinturas, vidros e porcelanas eram relatados para o dióxido. ${ }^{39,43}$ A citação quanto ao emprego na produção de aço só apareceria pela primeira vez em 1861, mas ainda sem fazer menção ao conversor de Bessemer (usavam-se os tradicionais cadinhos). ${ }^{44}$

É interessante citar que o emprego do manganês em dosagem química (permanganometria) já era praticado na Escola Polytechnica do Rio de Janeiro (atual Escola Politécnica da Universidade Federal do Rio de Janeiro) na década de $1880 .{ }^{45}$

\section{O início da exploração do manganês no Brasil}

Antes do início da exploração comercial, houve tentativas que não foram adiante. Em 1887, João Belisário Ribeiro de Almeida

Tabela 2. Exportações de minério de manganês do Brasil, 1898-2017 13,33-35

\begin{tabular}{|c|c|c|c|c|c|c|c|}
\hline Ano & Exportação $\left(10^{3} \mathrm{t}\right)$ & Ano & Exportação $\left(10^{3} \mathrm{t}\right)$ & Ano & Exportação $\left(10^{3} \mathrm{t}\right)$ & Ano & Exportação $\left(10^{3} \mathrm{t}\right)$ \\
\hline 1898 & 45,7 & 1928 & 362 & 1958 & 1.250 & 1988 & 411 \\
\hline 1899 & 62,3 & 1929 & 293 & 1959 & 942 & 1989 & 952 \\
\hline 1900 & $88^{* 1}$ & 1930 & 192 & 1960 & 866 & 1990 & 868 \\
\hline 1901 & $98^{* 2}$ & 1931 & 96 & 1961 & 868 & 1991 & 854 \\
\hline 1902 & 157 & 1932 & 21 & 1962 & 759 & 1992 & 696 \\
\hline 1903 & $162^{* 3}$ & 1933 & 25 & 1963 & 841 & 1993 & 804 \\
\hline 1904 & 208 & 1934 & 2 & 1964 & 833 & 1994 & 906 \\
\hline 1905 & 224 & 1935 & 61 & 1965 & 1.068 & 1995 & 1.248 \\
\hline 1906 & 121 & 1936 & 166 & 1966 & 957 & 1996 & 989 \\
\hline 1907 & 237 & 1937 & 247 & 1967 & 542 & 1997 & 983 \\
\hline 1908 & 166 & 1938 & 237 & 1968 & 1.124 & 1998 & 1.170 \\
\hline 1909 & 241 & 1939 & 189 & 1969 & 861 & 1999 & 599 \\
\hline 1910 & 254 & 1940 & 223 & 1970 & 1.588 & 2000 & 1.026 \\
\hline 1911 & 174 & 1941 & 437 & 1971 & 1.797 & 2001 & 1.022 \\
\hline 1912 & 155 & 1942 & 306 & 1972 & 1.172 & 2002 & 903 \\
\hline 1913 & 122 & 1943 & 276 & 1973 & 788 & 2003 & 1.058 \\
\hline 1914 & 184 & 1944 & 147 & 1974 & 1.493 & 2004 & 1.862 \\
\hline 1915 & 289 & 1945 & 245 & 1975 & 1.557 & 2005 & 1.826 \\
\hline 1916 & 503 & 1946 & 149 & 1976 & 1.073 & 2006 & 1.135 \\
\hline 1917 & 533 & 1947 & 142 & 1977 & 571 & 2007 & 1.288 \\
\hline 1918 & 393 & 1948 & 141 & 1978 & 895 & 2008 & 2.034 \\
\hline 1919 & 206 & 1949 & 150 & 1979 & 1.187 & 2009 & 1.609 \\
\hline 1920 & 254 & 1950 & 148 & 1980 & 1.037 & 2010 & 2.327 \\
\hline 1921 & 276 & 1951 & 120 & 1981 & 1.018 & 2011 & 2.091 \\
\hline 1922 & 341 & 1952 & 161 & 1982 & 990 & 2012 & 1.558 \\
\hline 1923 & 236 & 1953 & 166 & 1983 & 747 & 2013 & 1.835 \\
\hline 1924 & 159 & 1954 & 163 & 1984 & 879 & 2014 & 2.049 \\
\hline 1925 & 312 & 1955 & 177 & 1985 & 901 & 2015 & 1.898 \\
\hline 1926 & 320 & 1956 & 260 & 1986 & 704 & 2016 & 2.010 \\
\hline 1927 & 242 & 1957 & 950 & 1987 & 631 & 2017 & 2.683 \\
\hline
\end{tabular}

${ }^{1} 128,2$ mil t; ${ }^{34292,6}$ mil t; ${ }^{343} 217,7$ mil t. ${ }^{34}$ 
(1841-1906) protocolou junto à Câmara Municipal de Niterói um pedido de exploração de dióxido de manganês nas terras de sua fazenda entre Niterói e Maricá, municípios da Província do Rio de Janeiro. ${ }^{46}$ Em 1890, a Companhia Extractiva de Manganez se constituiu para extrair da província de Santa Catarina, dentre outros, os minérios de manganês ali existentes. ${ }^{47}$ Nesse mesmo ano dois empreendedores pediram permissão ao governo da Província de Goyaz para explorar em Santa Luzia ferro, manganês e outros minérios. ${ }^{48}$

A exploração comercial do manganês teve início no estado de Minas Gerais. A primeira planta entrou em operação em 1893 (Usina Wigg) em Miguel Burnier. ${ }^{13}$ Logo em seguida depósitos na região de Queluz (atual Conselheiro Lafaiete) foram identificados, cuja exploração teve início em $1896 .^{8}$ O principal deles, o Morro da Mina, foi responsável por grande parte da produção brasileira destinada aos Estados Unidos até 1961. ${ }^{8}$ Os trabalhos do geólogo norte-americano Orville Derby (1851-1915) foram importantes para destacar o potencial daquela região e de outras do Brasil para a produção de manganês. ${ }^{49}$ Conselheiro Lafaiete era considerada no período áureo de sua produção a "Cidade do Manganês" . ${ }^{49}$ Em 1912, descobriram-se depósitos em São João Del Rei, muito explorados na I e II Guerras Mundiais. ${ }^{8,50}$ Citam-se ainda a entrada em operação de outras jazidas na região do Quadrilátero Ferrífero nos anos 1910. ${ }^{8,50}$ O estado da Bahia era o segundo produtor nacional: afora Nazaré, a jazida de Santo Antônio de Jesus (Maraú), descrita em 1898, entrou em operação. ${ }^{8}$

\section{O manganês inicia seu ciclo como commodity mineral de exportação}

A partir de 1894, o manganês passou à condição de uma dos itens de nossa pauta de exportações, e o Brasil se tornou um importante fornecedor mundial desse insumo, viabilizado pela chegada da Estrada de Ferro Central do Brasil (EFCB) a Queluz e região do entorno. ${ }^{8,13} \mathrm{O}$ manganês de Minas Gerais figurava "como grande fornecedor nos principais mercados da Europa e da América do Norte". ${ }^{51} \mathrm{O}$ mineral oriundo do Brasil possuía duas vantagens em termos de concorrência com outros fornecedores: o teor de manganês era elevado (até $55 \%$ em massa) e o teor de fósforo era muito baixo $(<0,18 \% \mathrm{~m} / \mathrm{m}) \cdot{ }^{13}$ Havia ainda a presença de "lindas amostras de silicato de manganês, a rodonita, de uma bela cor rósea carregada, podendo prestar-se ao fabrico de artefatos de ornamentação". ${ }^{46}$ Aqueles que possuíam manganês em suas propriedades logo o ofereciam para quem quisesse explorá-lo, como no exemplo apresentado na Figura $6 .^{52}$

\section{VENDE-SE}

\section{Na Fazenda do Ribeirão, na estação de Alfredo de Vasconcellos, próximo á linha de ferro, dois kilometros, uma grande jazida de minerio manganez; para tratar com o proprietario da fazenda acima.}

Figura 6. Reprodução de um anúncio de venda de uma mina de manganês em uma fazenda em Alfredo de Vasconcellos, Minas Gerais, publicada em jornal de grande circulação na Capital Federal (Rio de Janeiro) de janeiro a setembro de $1901^{52}$

A Usina Wigg, implantada por Carlos Galignaino da Costa Wigg (1855-1931), significou "um grande passo alcançado pela indústria metalúrgica no país, tendo a primazia de ser o único e o primeiro montado em Minas Gerais". ${ }^{53}$ Tal fato coincidia com o grande impulso que a siderurgia tomava no mundo. ${ }^{54} \mathrm{~A}$ produção mundial de aço atingiu 28,3 milhões de t em 1900 e 60,3 milhões de t em 1910, o que exigia cada vez mais minério de manganês a fim de atender à demanda. Isso fez com que esse elemento fosse reconhecido como estratégico, insumo indispensável para a produção de aço ${ }^{8,13}$ Nos primeiros cinco anos, a Usina exportou as seguintes quantidades de minério de manganês: ${ }^{54} 1894,1.902$ t; $1895,7.593$ t; 1896, 12.454 t; 1897, 10.518 t; 1898, 7.894 t. Ela se situava ao lado de jazidas de ferro, manganês e calcário, no entroncamento de importante vias férreas, e contava com abundantes recursos naturais como água e lenha. ${ }^{55}$ Uma parceria com a Escola de Minas de Ouro Preto, previa supervisão técnica à produção de minério de manganês. ${ }^{56}$

Depois do auge da mineração de ouro no século XVIII, o manganês começou a disputar com ele a posição de principal commodity mineral em valor de exportação a partir do início do século XX, sendo a pauta de exportações desse segmento complementada por areias monazíticas, pedras preciosas, cobre, platina, dentre outros (Tabela 3). ${ }^{57} \mathrm{~A}$ principal receita de exportação era devida ao café, quase duzentas vezes a do manganês $\left(10^{\circ}\right.$ colocado), seguido da borracha (sessenta vezes). ${ }^{58}$ Em 1905, a guerra russo-japonesa e a greve nas minas de manganês no Cáucaso elevaram as cotações do manganês no mercado mundial, o que estimulou a lavra e a exportação do minério brasileiro. ${ }^{8,13} \mathrm{O}$ principal mercado importador nessa época era a Inglaterra. ${ }^{59}$

Tabela 3. Valores das exportações de ouro e manganês nas primeiras três décadas do século $\mathrm{XX}^{57}$

\begin{tabular}{lccc}
\hline \multirow{2}{*}{ Ano } & \multicolumn{2}{c}{ Valor de exportação (contos de réis) } & \multirow{2}{*}{ Referência } \\
\cline { 2 - 3 } & Ouro (barra) & Manganês (minério) & \\
\hline 1901 & $9.628 .366 \$ 000$ & $2.841 .948 \$ 000$ & 58 \\
1903 & $4.165 .000 \$ 000$ & $2.204 .000 \$ 000$ & 57 \\
1904 & $3.718 .306 \$ 000$ & $2.727 .102 \$ 000$ & 57 \\
1905 & $3.734 .469 \$ 000$ & $2.958 .462 \$ 000$ & 57 \\
1908 & $4.008 .350 \$ 000$ & $3.939 .585 \$ 000$ & 60 \\
1913 & $5.512 .000 \$ 000$ & $2.721 .000 \$ 000$ & 62 \\
1914 & $7.212 .000 \$ 000$ & $4.680 .000 \$ 000$ & 62 \\
1915 & $9.563 .000 \$ 000$ & $10.530 .000 \$ 000$ & 62 \\
1916 & $9.524 .000 \$ 000$ & $29.504 .000 \$ 000$ & 62 \\
1917 & $8.934 .000 \$ 000$ & $57.284 .000 \$ 000$ & 62 \\
1918 & Zero & $42.822 .000 \$ 000$ & 66 \\
1925 & $10.319 .000 \$ 000$ & $31.476 .000 \$ 000$ & 66 \\
1928 & $15.974 .000 \$ 000$ & $37.044 .000 \$ 000$ & 66 \\
\hline
\end{tabular}

Já na década seguinte, o manganês assumiu a dianteira de nossa pauta de exportações de commodities minerais (mais de $80 \%$ do valor exportado desse segmento). No período 1917-1919, ele respondia pela $5^{\text {a }}$ maior receita de exportação, atrás de café, borracha, açúcar e carne congelada. ${ }^{60-62}$ Três fatores contribuíram para isso: o aumento da produção do minério de manganês, particularmente a partir da I Guerra Mundial, a enorme elevação de seu valor de mercado em função do mesmo evento, ${ }^{63}$ e a proibição de exportação de ouro para que fosse empregado como reserva monetária (lastro para emissão de papel moeda e títulos). ${ }^{61,64}$ A Inglaterra deixou de importar, e os Estados Unidos passaram a ser o maior cliente do minério brasileiro. ${ }^{59}$ No auge da I Guerra Mundial, o Brasil foi o maior produtor mundial, praticamente todo proveniente de Minas Gerais (o maior produtor) e da Bahia. ${ }^{65}$

Na fase final da I Guerra Mundial Richard Paul Momsen (1891-1965), vice-cônsul em exercício dos Estados Unidos no Brasil, 
enviou a seguinte comunicação:67 "The War Trade Board proibiu depois do dia 20 de junho de 1918 a importação do minério de manganês proveniente da Ásia e da Australásia. Este regulamento foi posto em vigor devido ao fato de poder-se obter o referido minério em regiões menos afastadas, poupando-se desse modo grande tonelagem. Esta proibição não restringe de nenhum modo a exportação do manganês de origem brasileira, que é atualmente é a fonte da indústria do aço dos Estados Unidos." O final do conflito resultou num excesso de estoque de aço nos Estados Unidos e a retomada da importação do minério das fontes que forneciam à Europa antes da guerra (Rússia e Índia).$^{59} \mathrm{O}$ resultado foi a queda das exportações do minério brasileiro nos anos que se seguiram à I Guerra Mundial. ${ }^{59}$ Mesmo a expansão das siderúrgicas pelo mundo não compensaria a demanda suprimida com o final do conflito, o que significava que o preço da commodity não alcançaria mais os níveis vistos em meados dos anos $1910 .{ }^{59}$

\section{A dependência excessiva do manganês}

Nos anos 1920, o manganês permanecia como a principal commodity mineral de exportação. Em contraste à reconhecida riqueza e diversidade de nosso patrimônio mineral, constatava-se que "nos outros minérios e produtos de origem mineral (...) não tem havido progresso nesse particular. Exportamos nesse agrupamento águas minerais, areia monazítica, cal, cristal, ferro gusa, mica, minério de ferro, fósforos, sal, telhas de barro, terras e barro, mas tudo em muito pequena porporção". 68

Outro problema atormentava as empresas produtoras de minério de manganês: o custo do frete, na época centrado em transporte ferroviário pelas linhas da EFCB. ${ }^{53,54}$ Os aumentos das tarifas colocavam enormes dificuldades para dar competitividade ao minério no mercado externo. ${ }^{53}$ Pela mesma razão, face aos custos proibitivos de transporte do minério de manganês de Mato Grosso (Urucum) e Goiás, era em Minas que o parque existente devia se desenvolver graças ao concurso das estradas de ferro a fim de atender à demanda externa de aço, ${ }^{63} \mathrm{e}$ isso apesar dos constantes atritos entre os produtores, os usineiros, a EFCB e o Governo Federal. ${ }^{56}$

Os pequenos empreendimentos produtores sofriam uma concorrência desleal com as grandes mineradoras em operação no Brasil: “ $O$ processo que os magnatas que conseguiram açambarcar o comércio de manganês no Brasil têm empregado para matar a indústria dos pequenos produtores é muito simples: gozando do prestígio que lhes dava o dinheiro em uma época de corrupção como a que findou, eles sempre conseguiram redução de fretes para seus minérios de teores alto e médio, ao mesmo passo que faziam conservar uma taxa exagerada para os minérios de baixa porcentagem, de tal maneira que se tornava absolutamente impraticável em épocas normais o comércio dessa qualidade de minério. (...) Como resultado, a exportação faz-se exclusivamente por três firmas, que exploram o minério alto (...)". ${ }^{15}$ Segundo Rodolpho Bahia (1884-1948), diretor da Cia. de Mineração de Penedo, "o minério baixo representa incontestavelmente $80 \%$ do minério de manganês existente no Brasil. Algumas firmas europeias e mesmo norte-americanas têm enviado aqui representantes seus para efetuar a compra de minério aos pequenos produtores, fazendo estoque no Rio de Janeiro, para exportar posteriormente. Essas tentativas todas têm fracassado porque, sobrecarregado de despesas excessivas em proporção ao seu teor, o minério baixo só lhes podia dar prejuízo. (...) Todos se retiraram do mercado." 15

Cabe esclarecer que, diferentemente dos grandes conglomerados de exploração mineral de hoje, nas primeiras décadas do século XX a produção estava pulverizada em diversas empresas de atuação local ou regional: Sociedade Geral das Minas de Manganês Gonçalves Ramos, que explorava as jazidas do Paiva, Colatino, Michaela e Piquiri; A. Thun, que explorava as jazidas de Água Preta, Jurema, Bom Jardim e
Olhos D’Água; Sociedade Anônima de Minas de Manganês de Ouro Preto (jazidas de São Gonçalo e Cocuruto); Sociedade Brasileira de Mineração (jazida de Água Preta); Companhia Morro da Mina; Sociedade Geral das Minas de Manganez; Companhia de Mineração do Brasil; Companhia Manganez Queluz de Minas e Cia. Santa Matilde. ${ }^{26}$ Empresas belgas dirigiram-se para a região de Ouro Preto como La Société Anonyme des Mines de Manganèse de Ouro Preto, Compagnie Minière Belgo-Brésiliénne, Société Belge-Brésiliene de Três Cruzes et Extensions. Os empreendimentos que tinham as maiores produções e que influenciavam o mercado do manganês no país eram A. Thun, Companhia Manganez Queluz de Minas e Cia. Santa Matilde. ${ }^{15}$

Os Estados Unidos continuavam a ser o grande comprador do minério de manganês brasileiro. A justificativa para isso é que "segundo a opinião dos mais abalizados geólogos norte-americanos, a indústria de mineração de manganês nos Estados Unidos, os maiores importadores de nosso minério, nunca será capaz de satisfazer às necessidades internas por causa da insuficiência de suas reservas, aconselhando, por isso, o respectivo Governo a preservar as suas pequenas reservas de alto teor para os casos de emergência, facilitando, por conseguinte, a importação de minérios estrangeiros." 65 Surgiam as primeiras opiniões de que havia necessidade de se tomar medidas acauteladoras para preservar nossas reservas de minério de manganês, pois "dentro em breve se deverá desenvolver a indústria siderúrgica, acrescentando a circunstância de que nas nossas jazidas só é procurado o minério do mais alto teor, abandonando-se minérios que correspondem, em teor, aos melhores norte-americanos acima referidos. ${ }^{65,69} \mathrm{~A}$ ideia é que se desenvolvesse no Brasil a indústria de ferro-manganês, que seria exportado para os Estados Unidos (isto é, exportar um produto de maior valor agregado e não o minério bruto). ${ }^{69,70}$ Temia-se que o Brasil fosse reduzido a um mero fornecedor de minério de manganês, e que a implementação de seu parque siderúrgico tivesse o risco de ser desprovido dos minérios de melhor qualidade. $^{70,71}$ Porém, segundo levantamentos feitos pelo Serviço Geológico Mineralógico do Brasil em 1926, quanto às reservas conhecidas e novas descobertas de manganês em nosso território, "tendo em vista o desenvolvimento da nossa indústria siderúrgica, concluiu-se que não há inconveniente em permitir a exportação anual de 300 mil t de minério de manganês durante os próximos 50 anos (...)". ${ }^{69}$

\section{Anos 1930: ameaças ao comércio do minério de manganês brasileiro}

Em 1930, já se detectava que "o minério de manganês, que já ocupou a liderança de produção no comercio mundial, hoje vai perdendo posição". ${ }^{71}$ As receitas auferidas com a exportação de commodities minerais, especialmente o manganês, sofreram sensível queda: "a principal causa da ruína das exportações de minério foi a concorrência do produto similar exportado pela Rússia e Sul da África, países estes cujo preço de produção, muito inferior ao nosso, impediu que o principal consumidor de nosso minério, os Estados Unidos da América do Norte, continuasse a se abastecer no Brasil." 72 A queda das importações desse país é clara a partir dos dados da Tabela 4. A solução sugerida foi atuar no custo dos fretes (ferroviário e marítimo) e das taxas alfandegárias.

Os Estados Unidos, num esforço de pesquisa e desenvolvimento para reduzir sua dependência do manganês do estrangeiro, divulgou que "Já existe um processo desenvolvido pelo Bureau of Mines, permitindo a produção de ferro-manganês partindo de minérios de ferro manganesíferos contendo desde cerca de $8 \%$ de manganês. A tendência da política americana é para eliminar a importação de minérios de manganês com a utilização do manganês doméstico, mediante processos de concentração e de tratamento convenientes e, sobretudo, com 
a taxação dos minérios importados" ${ }^{73}$ Contudo, a II Guerra Mundial obrigou a interrupção dessa política, face ao esforço de guerra, voltando a favorecer a importação do manganês brasileiro. ${ }^{74}$

Tabela 4. Aquisições de minério de manganês brasileiro pelos Estados Unidos $^{72}$

\begin{tabular}{cc}
\hline Ano & Quantidade exportada para os EUA $\left(10^{3} \mathrm{t}\right)$ \\
\hline 1929 & 157 \\
1930 & 210 \\
1931 & 150 \\
1932 & 21 \\
1933 e 1934 & 0 \\
\hline
\end{tabular}

Outro ponto levantado para enfrentar essa situação foi estimular de forma definitiva no Brasil a indústria siderúrgica, exatamente o maior consumidor de minério de manganês: "a produção de ferro-manganês será economicamente mais indicada para o Brasil em virtude do pequeno volume das nossas reservas desse mineral (250.000.000 t) em relação às de ferro. As reservas brasileiras de ferro, consideradas praticamente inesgotáveis, asseguram ao Brasil capacidade de realizar uma grande indústria metalúrgica. A aplicação crescente das ligas de manganês nessa indústria indica que devemos dispor parcimoniosamente das nossas reservas, e não nos é absolutamente conveniente a exportação do minério, como até hoje temos praticado." "75 Mais tarde, houve uma retificação: "devemos exportar os nossos minérios de manganês enquanto podemos concorrer no mercado mundial, deixando como reservas para o futuro consumo do país os minérios de baixo teor ou os que, pela sua situação, não podem ser exportados." ${ }^{33}$

O parque siderúrgico brasileiro no início do século XX tinha muito pouca expressão. ${ }^{76} \mathrm{Em}$ 1918, iniciou-se a produção de aço e de laminados leves. Entre 1919 e 1929, surgiu uma série de novas empresas, três das quais se destacam por avançarem às etapas da produção de aço e laminação-Belgo-Mineira, Cia. Brasileira de Mineração e Metalurgia e Cia. Brasileira de Usinas Metalúrgicas. Em 1929, o país já produzia 33,7 mil t de ferro-gusa, 27,4 mil t de aço e 29,8 mil t de laminados. A partir especialmente da segunda metade da década de 1930, houve uma nova onda de investimento no setor, com criação de novas empresas e expansão das já existentes. Em 1940, a produção foi de 186 mil t de ferro-gusa, 141 mil t de aço e 135 mil t de laminados. ${ }^{76} \mathrm{O}$ governo do então Presidente Getúlio Dorneles Vargas (1882-1954) tinha com umas das suas principais metas o crescimento e a nacionalização da indústria de base e, para tanto, visualizava a necessidade de reduzir a dependência brasileira do aço importado. A exportação do minério bruto deixava de prevalecer sobre a industrialização no país. A capacidade produtiva siderúrgica instalada em 1943 no país - da ordem de 280 mil t/ano de ferro-gusa e aço e de 170 mil t/ano de laminados - comparava-se à capacidade planejada da usina de Volta Redonda da Companhia Siderúrgica Nacional, então em construção, que era de em torno de 300 mil t/ano de laminados. ${ }^{76}$

O fato é que de 1900 a 1957 a produção total brasileira de manganês registrada foi da ordem de 14 milhões de toneladas, das quais cerca de 13 milhões foram destinadas à exportação, especialmente para os Estados Unidos. ${ }^{11,16}$ As duas guerras mundiais registraram picos de produção: Minas Gerais registrou exportações de quase 900 mil t ao longo da I Guerra Mundial, e chegou a atingir 430 mil t em 1941, durante a II Guerra Mundial. ${ }^{13}$

\section{Anos 1940: preocupações analíticas e novas jazidas}

A literatura científica dessa época contém numerosos estudos que se preocuparam com a análise de manganês em seus minérios, buscando dosagens mais precisas e reprodutíveis. Amostras de pirolusita das várias jazidas brasileiras eram invariavelmente usadas. Como os teores de impurezas podem variar significativamente de uma jazida a outra do mesmo minério, os métodos analíticos deviam ser robustos o bastante para dar conta dessas variações, pois isso determinaria a classificação do minério (alto, médio e baixo teor). Tal assunto mobilizou a Associação Brasileira de Normas Técnicas (ABNT), que recomendava em 1943 o método do persulfato, ${ }^{74}$ mas que tinha a possível interferência do ferro na exatidão e precisão desse método, aliás, um problema comum aos minérios de manganês de Minas Gerais, Bahia, Goiás e Mato Grosso. Isso exigia um fator de correção, objeto de estudos ${ }^{77}$ a partir de soluções padrão ou padrões de referência fornecidos por organismos como o Bureau of Standards, dos Estados Unidos.

Em um grupo de estudos, a determinação das impurezas (Fe, Si, $\mathrm{Al}, \mathrm{P}, \mathrm{S}, \mathrm{Ti}$ ) em minérios de manganês por métodos gravimétricos ou titulométricos foi desenvolvida, em particular no IPT (Instituto de Pesquisas Tecnológicas de São Paulo). ${ }^{78,79}$

Em contraposição aos métodos tradicionais de dosagem de $\mathrm{MnO}_{2}$ por titulação de oxirredução com oxalato ou sulfato ferroso, o uso de solução padrão de arsenito em meio ácido conduz a resultados mais exatos e precisos, além de ser mais rápido e dispensar atmosfera protetora.$^{80}$ Outra tentativa envolveu o uso de peróxido de hidrogênio como agente redutor, também em meio ácido. ${ }^{81}$

Passada a fase inicial de descoberta e exploração das jazidas pioneiras em Minas Gerais, novos depósitos foram descritos em Itabira (1945). ${ }^{82}$ Enquanto isso, após tentativas infrutíferas, a Mina de Urucum (Mato Grosso) entrou em operação em 1940, escoando sua produção pela bacia do Rio Paraguai. ${ }^{16} \mathrm{Na}$ Bahia, o distrito manganífero de Urandi foi descrito em 1948. ${ }^{8}$ Mas foi no Amapá que seu deu a descoberta mais espetacular de uma jazida de manganês, a mina da Serra do Navio. Em 1934, o engenheiro Josalfredo Borges, percorrendo o vale do Rio Amapari a serviço do DNPM, constatou a existência de pequenas ocorrências de manganês. Entretanto, possivelmente por haver retratado a presunção de que se tratava de manifestação geológica isolada, sem indícios de sequência e sem qualquer valor econômico, ficou relegado ao esquecimento. ${ }^{8,83}$ Em 1941, Mário Cruz (1897-1973), pequeno comerciante, em uma de suas viagens à região de garimpo de ouro da bacia do Rio Amapari, colheu amostras "de uma pedra escura e bastante densa" como lastro para sua canoa. ${ }^{74}$ A partir de um edital lançado pelo governador do então Território do Amapá, Janari Gentil Nunes (1912-1984), que buscava descobrir jazidas de ferro, Mário entregou tais amostras ao governador, que as enviou ao Rio de Janeiro e a Belo Horizonte. ${ }^{8,74}$ Os resultados indicavam que se tratavam de minério de manganês de alto teor e equivalente aos melhores conhecidos no mundo àquela época. ${ }^{83,84}$ Pesquisadores logo se interessaram em estudar e entender aquela jazida recém-descoberta, ${ }^{85}$ realçada por outras descobertas nos anos seguintes: cromo, ferro, titânio, tântalo, estanho, ouro, diamante, etc. ${ }^{86} \mathrm{O}$ então longínquo e desconhecido Amapá se transformava em um território com potencial e vocação para entrar numa era de progresso. ${ }^{74,87}$

Naquela época, o controle das maiores jazidas conhecidas pela então União Soviética (responsável por cerca de $75 \%$ da produção mundial $)^{13}$ e a consequente ameaça de insuficiência de manganês para abastecer à demanda norte-americana e de seus aliados, fizeram com que o acesso às reservas amapaenses fosse tratado como assunto emergencial. ${ }^{13}$ Tais jazidas estavam estrategicamente localizadas, visto sua maior proximidade com os Estados Unidos e a Europa, reduzindo significativamente os custos com transporte, ${ }^{87}$ especialmente quando se observa que as demais reservas brasileiras se encontravam em Mato Grosso, Bahia e Minas Gerais: "O distrito manganífero de Amapari, descoberto justo na hora em que a prudência aconselhava a maior parcimônia nas exportações de manganês de Minas Gerais, 
reservando-o para nossa siderurgia, dista menos de $200 \mathrm{~km}$ da margem do Rio Amazonas, e daí a apenas 3.000 milhas dos portos norte-americanos". ${ }^{74}$

Após uma espécie de concorrência organizada por Janari Gentil Nunes, o direito de explorá-la foi concedido pelo governo federal, em dezembro de 1947, à Indústria e Comércio de Minérios S.A. (ICOMI) ${ }^{8,88}$ Dois anos depois, sob a alegação da necessidade de aporte técnico e de recursos financeiros, a ICOMI associou-se a Bethlehem Steel Company, uma das gigantescas corporações norte-americanas produtoras de aço daquela época, que passou a ter $49 \%$ do capital da empresa; os restantes $51 \%$ estavam na mão de brasileiros natos. ${ }^{88}$

A exploração do manganês da Serra do Navio foi a primeira experiência de mineração industrial na Amazônia. ${ }^{88}$ Essa mina foi a primeira em larga escala no país a contar com um sistema de transporte, incluindo uma ferrovia $(193 \mathrm{~km})$, o porto de Santana, e uma estrutura mecanizada de apoio à exploração. ${ }^{8,83}$

Em 1949, a primeira balsa, construída no Amapá para levar o minério da Serra do Navio para o porto de Santana, foi lançada. ${ }^{89} \mathrm{Em}$ outubro de 1956, foi realizado o primeiro carregamento de grande porte de minério da Serra de Navio até Santana - feito festejado em uma cerimônia que contou com a presença do então presidente da República, Juscelino Kubitschek (1902-1976)..$^{88}$

\section{Anos 1950: reposicionamento do mercado interno e externo do manganês}

Até 1956, Minas Gerais foi o principal estado produtor de minério de manganês. No ano seguinte, foi suplantado pelo Amapá exatamente graças à entrada em operação da mina da Serra do Navio. Isso se refletiu na elevação substancial da produção de minério no país: na faixa 140-180 mil t/ano entre 1945 e 1955, para mais de 1 milhão em $1958 . .^{16,35}$

O minério de ferro passou a ser a principal commodity mineral da pauta de exportação brasileira, suplantando o minério de manganês a partir de 1946 (Tabela 5). ${ }^{90}$ A partir da década de 1950, sua posição se consolidou por conta do extraordinário aumento de sua produção, tanto para atender à expansão da siderurgia brasileira, como ao mercado externo: de 715 mil t em 1945, para 1,9 milhão em 1950, 4,1 milhões em 1955 e 5,2 milhões de t em $1960 .{ }^{90}$ Isso compensava amplamente o preço mais elevado do minério de manganês frente ao de ferro (2,5 a 4 vezes) no mesmo período. ${ }^{90}$

Em termos do manganês explorado no Brasil, aquele proveniente do Amapá e da Bahia foi dirigido à exportação, notadamente aos Estados Unidos, sendo a produção de Minas Gerais, Mato Grosso e Goiás direcionada ao mercado interno, visto que as indústrias siderúrgicas nacionais se concentravam na Região Sudeste. ${ }^{8,33}$ Isso criou um certo paradoxo na política mineral do manganês: enquanto as melhores jazidas eram direcionadas à exportação, eram as que estavam em exploração desde o final do século XIX, já dando sinais de esgotamento, que se situavam próximas das usinas siderúrgicas. ${ }^{8}$ Essa contradição realimentou a discussão sobre o papel do Brasil como um mero fornecedor de commodities minerais, alimentado a siderurgia em outros países, fragilizando o mercado interno em termos de acesso a um insumo tão importante para a produção de aço ${ }^{8,20}$ No mercado interno, o custo do frete sempre foi um sério entrave ao aproveitamento interno de manganês de jazidas distantes como as de Urucum ou da Serra do Navio, chegando a ser mais atrativo economicamente importar minério de manganês do Gabão para as siderúrgicas mineiras. ${ }^{8}$

\section{Anos 1960-1970: novas fronteiras e oscilações de mercado}

No Pará, a partir de um dos primeiros programas de prospecção sistemáticas realizados no Brasil, a Companhia Desenvolvimento de
Tabela 5. Valores das exportações de minérios de ferro e de manganês nas décadas de 1940 e $1950^{90}$

\begin{tabular}{lcc}
\hline \multirow{2}{*}{ Ano } & \multicolumn{2}{c}{ Valor de exportação (expressos em cruzeiros) } \\
\cline { 2 - 3 } & Ferro (minério) & Manganês (minério) \\
\hline 1943 & 24.972 .000 & 26.237 .000 \\
1944 & 26.932 .000 & 29.613 .000 \\
1945 & 19.988 .000 & 26.996 .000 \\
1946 & 19.266 .000 & 12.737 .000 \\
1947 & 25.828 .000 & 16.610 .000 \\
1948 & 78.862 .000 & 20.839 .000 \\
1949 & 91.076 .000 & 23.626 .000 \\
1950 & 64.382 .000 & 25.545 .000 \\
1952 & 312.539 .000 & 39.221 .000 \\
1954 & 747.030 .000 & 33.445 .000 \\
1956 & 407.277 .000 & 85.663 .000 \\
1958 & 616.376 .000 & $265.638 .000 *$ \\
\hline
\end{tabular}

*A mina da Serra do Navio (AP) entrou em operação em 1957

Indústrias Minerais (CODIM) revelou a presença de manganês na Serra do Sereno (1966), na Serra de Buritirama (1967) e no Igarapé Azul (1971), todas na bacia do Rio Itacaiúnas. ${ }^{8}$

O mercado do manganês sofreu fortes oscilações de preço no período, sendo verificada uma contínua redução dos valores entre 1955 e 1971: de mais de US\$ 100 a tonelada antes da entrada em operação da mina da Serra do Navio, o preço caiu para apenas US\$ 21 em $1971 .{ }^{33}$ Isso se deveu em grande parte à entrada em operação de minas no Gabão e na Austrália. ${ }^{8,13}$

Até meados dos anos 1970, na Serra do Navio, o minério de manganês de granulometria mais fina não tinha aplicação no mercado. Com o final da lavra da região mais rica em manganês e face a modificações no mercado mundial, foi construída uma usina de pelotização nas proximidades do porto da Vila do Elesbão, área industrial do município de Santana. ${ }^{91,92}$ Ela funcionou até $1983 .{ }^{88}$ Durante a pelotização, a $900-1000{ }^{\circ} \mathrm{C}$, aglomeravam-se os finos em pelotas de cerca de 1 $\mathrm{cm}$, o que permitia sua comercialização. ${ }^{88}$ Outro dado relevante foi a mudança do perfil do mercado importador desse minério: a paulatina redução da destinação aos Estados Unidos, concomitantemente ao aumento da destinação às siderúrgicas europeias. ${ }^{88,91}$

\section{Anos 1980-2000: mudança do perfil de produção no Brasil}

Depois de um longo período de liderança, o Amapá começou a declinar sua produção face aos sinais de esgotamento da mina da Serra do Navio. Em 1986, Amapá, Pará e Minas Gerais tinham produções próximas. Seis anos depois, o Amapá cedia a liderança para Minas Gerais, suplantada um ano depois pelo Pará, que detém até hoje a dianteira na produção. ${ }^{93} \mathrm{O}$ já estado do Mato Grosso do Sul mostrava um enorme potencial ${ }^{93}$ investimentos posteriores em infraestrutura e transporte levaram esse estado à posição atual de segundo produtor nacional. ${ }^{2}$ Após 40 anos de atividade, com 50 milhões de $t$ de minério extraídos, a mina da Serra do Navio parou de produzir em 1997. ${ }^{87,88,91}$

A produção de minério de manganês cresceu no período, enquanto a mundial sofreu redução, em um mercado internacional relativamente estável, controlado pelos grandes consumidores e restrito a alguns poucos países que são grandes produtores. ${ }^{10,93} \mathrm{~A}$ produção brasileira de manganês também foi estimulada por um grande crescimento do parque siderúrgico nacional..$^{90}$ 


\section{PERSPECTIVAS DO MANGANÊS NO BRASIL}

Segundo o DNPM, o minério de manganês não deve ser substituído por outro equivalente em curto prazo, uma vez que seu custo de produção é relativamente baixo e as reservas descobertas e exploradas são suficientes para a demanda mundial para as próximas décadas. ${ }^{2,9,29}$

A reativação de usina de ferro-ligas em Corumbá (MS), paralisada desde 2009, é prevista pela mineira Granha Ligas, que produz ferro-silício-manganês (teor de manganês entre 12 e $16 \% \mathrm{~m} / \mathrm{m}$ ) e ferro-manganês "alto carbono" (74-78\% m/m de manganês e 7,5\% $\mathrm{m} / \mathrm{m}$ de carbono). $\mathrm{O}$ empreendimento deverá elevar a demanda por manganês e minério de ferro na região de Urucum.

Mudanças tecnológicas permitem hoje o uso siderúrgico de minérios de manganês de baixo teor depois de reprocessados por concentração, ${ }^{6}$ o que pode trazer novas frentes ou reativar antigas jazidas, ${ }^{3,16}$ o que inclui o processamento de depósitos pequenos. ${ }^{8} \mathrm{Nesses}$ casos, eles são concentrados (o teor em manganês é aumentado) ou transformados em ligas ferro-manganês. ${ }^{22}$

No Pará, será implantado pela VALE um projeto de adequação da usina de beneficiamento de manganês da mina do Azul, com base no desenvolvimento de tecnologia de reaproveitamento dos "finos" de minério depositados nas barragens de rejeito. A previsão é de 4,5 milhões de $t$ de minério a serem reaproveitados dos rejeitos da mina do Azul, prolongando com isso a vida útil da jazida. ${ }^{2,9,29} \mathrm{O}$ reaproveitamento do passivo da mina da Serra do Navio poderá recuperar o manganês remanescente (finos), além de viabilizar a exploração de alguma frente de lavra. ${ }^{88,91,92}$

A projeção da demanda interna de manganês para 2030 é de 4 milhões de t. O manganês continuará sendo um insumo de muito uso no Brasil, por causa da ampliação da capacidade produtiva da siderurgia e de produção de ferro-ligas contendo manganês. Cabe assinalar que atualmente as principais reservas e minas em produção encontram-se no Pará, voltadas, predominantemente à exportação, e distantes do parque siderúrgico nacional, concentrado na região Sudeste. ${ }^{12}$

A produção de manganês está estreitamente relacionada ao mercado consumidor, diminuindo ou aumentando de acordo com a sua necessidade. A demanda por manganês vem crescendo nos últimos anos impulsionada pela expansão da indústria de aço global. Esse crescimento está sendo dirigido pela expansão da indústria de aço chinesa que atualmente responde por quase $40 \%$ da produção mundial; por conta disso, o comércio mundial de manganês tem previsão de crescimento de aproximadamente $7 \%$ ao ano, durante os próximos cinco anos. ${ }^{23}$

A manutenção do Brasil em uma posição privilegiada entre os principais produtores mundiais de manganês depende do porte e qualidade de suas reservas. As jazidas que possuem maior teor são raras e poucos são os países que as detêm. No Brasil, por se tratarem de reservas amplas e de alto teor, a exploração do minério de manganês é viável economicamente, tendo em vista a demanda dos mercados consumidor interno e externo. ${ }^{11} \mathrm{O}$ setor é tradicional fornecedor no mercado internacional, com a média histórica da exportação de $30 \%$ da produção. É estratégico para o setor manter esse percentual de produção para venda nos mercados internacionais conquistados nos últimos 40-50 anos. ${ }^{11}$ Mesmo assim, o Brasil deve investir em pesquisas que apontem novas reservas a serem lavradas, para que a produção brasileira atenda à crescente demanda interna e dos mercados consumidores externos.

Segundo o Plano Nacional de Mineração 2030, a exploração do manganês prevê investimentos que chegarão a US\$ 62,3 milhões em 2030 em prospecção mineral, centrada na Bahia e na Região Norte, e de US\$ 682 milhões para novos empreendimentos e ampliação da capacidade produtiva, perdendo apenas para o ferro na categoria de minerais ferrosos. ${ }^{12}$
Existiam em 201894 concessões de lavra ativas, a maioria em Minas Gerais (39) e na Bahia (37). Havia 53 pedidos de pesquisa. Desse total, 23 são em Minas Gerais, 13 na Bahia e 8 no Pará. Dos 41 requerimentos de pesquisa, 15 estão em Roraima, 10 na Bahia, 7 no Pará e 6 em Rondônia. Por fim, estão vigentes 63 alvarás de pesquisa, com predominância da Bahia (38), seguida por Minas Gerais (8), Pará (6) e Rondônia (4). ${ }^{10,13}$

Com a exaustão estimada da Mina do Azul em um horizonte de 10 anos, o Brasil será pela primeira vez um player menos relevante no mercado internacional de manganês. À medida que as minas de manganês entrarem em processo de exaustão, a cotação desse bem mineral tenderá a valorizar-se, o que, por sua vez, viabilizará ocorrências de menor porte e com maior custo de produção. ${ }^{16}$

Por fim, a compatibilidade entre a exploração mineral e o meio-ambiente precisa ser considerada. Na fase final de produção da mina da Serra do Navio, devido às altas temperaturas do processo de pelotização das frações finas do minério, ${ }^{91,92} \mathrm{O}$ arsênio contido nele tornou-se solubilizável em condições ambientais. ${ }^{88,91,92}$ Os rejeitos da pelotização ${ }^{88}$ foram depositados em uma barragem situada ao lado da usina. ${ }^{92}$ Esses resíduos vieram a contaminar as águas da barragem e do subsolo em suas imediações. ${ }^{91}$ Como na época das chuvas a barragem transbordava, as águas dos igarapés Elesbão I e II, usadas pela população da Vila do Elesbão, município de Santana (AP), ${ }^{91,92}$ foram contaminadas por arsênio, conforme constatação da Secretaria de Meio Ambiente do Amapá. ${ }^{2}$

\section{CONCLUSÕES}

O Brasil tem um papel relevante na história da exploração e do emprego do minério de manganês. Enquanto o país se mantém entre os maiores produtores mundiais e detentores de reservas há mais de 100 anos, a exploração do minério foi fortemente influenciada pela demanda externa na maior parte do século XX, como mostram, por exemplo, os picos de produção ao longo da I e II Guerras Mundiais. O manganês brasileiro ajudou a alavancar as indústrias siderúrgicas norte-americana e europeia nas primeiras décadas do século XX, ao mesmo tempo em que o desenvolvimento de seu parque siderúrgico se deu de forma lenta, somente acelerando após a II Guerra Mundial. Embora ainda hoje a maior parte do minério seja exportada, em média esse percentual ultrapassou $92 \%$ nas primeiras seis décadas do século XX.

Os desafios de escoar a produção de jazidas de minérios de manganês distantes dos centros siderúrgicos foi e ainda é um problema característico do Brasil. A projeção de aumento das demandas interna e externa do elemento pressionará por investimentos em transporte e logística. $\mathrm{O}$ aproveitamento de rejeitos e finos de minérios e a prospecção de novas áreas produtoras ajudarão a manter o parque siderúrgico brasileiro suprido desse insumo essencial à produção de aço. As novas perspectivas do manganês no mercado da energia portátil projetam um aumento de sua importância estratégica para o futuro.

\section{REFERÊNCIAS}

1. Greenwood, N. N.; Earnshaw, A.; Chemistry of the Elements, $2^{\text {nd }}$ ed., Elsevier Butterworth-Heinemann: London, 2010, cap. 24; Rocha, R. A.; Afonso, J. C.; Quim. Nova Esc. 2012, 34, 103.

2. Dias, T. G.; Calixto, F.; Manganês, Recursos Minerais de Minas Gerais, Ministério das Minas e Energia: Brasília, 2018, 16 p.

3. Sampaio, J. A.; Andrade, M. C.; Dutra, A. J. B.; Penna, M. T. M. In Rochas \& Minerais Industriais - Usos e Especificações; Luz, A. B., Lins, F. A. F., eds.; $2^{\mathrm{a}}$ ed., Centro de Tecnologia Mineral: Rio de Janeiro, 2008, pp. 633

4. Weeks, M. E.; Discovery of the Elements, Journal of the Chemical Education, 1945, pp. 237. 
5. Christianson, D. W.; Prog. Biophys. Molec. Biol. 1997, 67, 252.

6. Erikson, Keith M.; Ascher, M. In Essential Metals in Medicine: Therapeutic Use and Toxicity of Metal Ions in the Clinic. Metal Ions in Life Sciences; Sigel, A., Freisinger, E., Sigel, R. K. O., Carver, P. L., eds.; De Gruyter GmbH: Berlin, 2019, pp. 253.

7. Santamaria, A. B.; Ind. J. Med. Res. 2008, 128, 484.

8. Abreu, S. F.; Recursos Minerais do Brasil, $2^{\mathrm{a}}$ ed., Instituto Nacional de Tecnologia: Rio de Janeiro, 1973, vol II, pp. 492.

9. Lima, T. M.; Neves, C. A. R.; Sumário Mineral Brasileiro 2015, Departamento Nacional de Produção Mineral: Brasília, 2015, pp. 80-82.

10. Anuário Mineral Brasileiro 2017, Ano-Base 2016. Brasília: Departamento Nacional de Produção Mineral, 2017, 43 p.

11. Quaresma, L. F.; Perfil da Mineração do Manganês - Relatório Técnico 19. Contrato $\mathrm{n}^{\circ} 48000.003155 / 2007-17$ : Desenvolvimento de estudos para elaboração do plano duodecenal (2010 - 2030) de geologia, mineração e transformação mineral. Ministério das Minas e Energia: Brasília, 2009, 40 p.

12. Plano Nacional de Mineração 2030 - Geologia, Mineração e Transformação Mineral. Ministério das Minas e Energia: Brasília, 2011, $180 \mathrm{p}$.

13. Heider, M.; Amarante, J. L.; In the Mine 2018, 72, 9.

14. O Jornal do Rio de Janeiro, 21 de novembro de 1948, p. 4.

15. O Manganez e a sua Producção - a luta entre o grande e o pequeno produtor. Correio da Manhã, Rio de Janeiro, 20 de dezembro de 1930, p. 10.

16. Heider, M.; Amarante, J. L.; In the Mine 2018, 73, 9

17. Paiva Netto, I. E.; An. Assoc. Quim. Bras. 1941, 1, 159; Paiva Netto, I. E.; An. Assoc. Quim. Bras. 1941, 1, 42; Paiva Netto, I. E.; An. Assoc. Quim. Bras. 1942, 1, 126.

18. Candia, M. A. F.; Girardi, V. A. V.; Boletim do Instituto de Geociências da USP 1979, 10, 19

19. Ribeiro Filho. E.; Boletim do Instituto de Geociências da USP 1973, 4 , 87.

20. Barbosa. A. F.; Almeida, F. F. M.; Nogueira Filho, J. V.; Santos, T. D. S.; Mazzarella, V.; Manganês. Geologia e Metalurgia, boletim no ${ }^{0}$ 19. São Paulo: Escola Politécnica da Universidade de São Paulo, 1959, 118 p.

21. Wertime, T. A.; The coming of the age of steel. University of Chicago Press: Chicago, 1962.

22. Drummond, J. A.; Pereira, M. A. P.; O Amapá nos tempos do Manganês: um estudo sobre o desenvolvimento de um estado amazônico - 19432000, Garamoud: Rio de Janeiro, 2007.

23. Santana, A. L.; Manganês. Departamento Nacional de Produção Mineral: Brasília, 2017, pp. 117.

24. Ibiapina, V. F.; Florentino, U. S.; Afonso, J. C.; Gante, V.; Vianna, C. A.; Mantovano, J. L.; Quim. Nova 2018, 41, 176.

25. Paulino, J. F.; Busnardo, N. G.; Afonso, J. C.; Quim. Nova 2007, 30, 718.

26. Silva, R. G.; Afonso, J. C.; Mahler, C. F.; Quim. Nova 2018, 41, 581

27. Pletcher, D.; Walsh, F. C.; Industrial Electrochemistry, $2^{\text {nd }}$ ed., Springer: Berlin-Heidelberg, 2012, pp. 275.

28. Silva, L. H. C. P.; Campos, H. D.; Silva, J. R. C.; Reis, E. M.; Summa Phytopathol. 2015, 41, 64.

29. Sistema de Análise das Informações de Comércio Exterior. MDIC - Ministério da Indústria, Comércio Exterior e Serviços, SECEX Secretaria de Comércio Exterior. Disponível em http://comexstat.mdic. gov.br/pt/home/, acessada em outubro 2019.

30. Informe Mineral, julho/dezembro 2012. Departamento Nacional de Produção Mineral: Brasília, 2012, p. 3; Informe Mineral, janeiro/junho 2018. Departamento Nacional de Produção Mineral: Brasília, 2012, p. 4.

31. Silva, B. O.; Câmara, S. C.; Afonso, J. C.; Neumann, R.; Alcover Neto, A.; Quim Nova 2011, 34, 812.

32. https://www.consumidormoderno.com.br/2019/02/13/energizadomercado-pilhas-brasil, acessada em outubro 2019.
33. Brasil em Dados '75. Rio Gráfica e Editora: Rio de Janeiro, 1975, pp. 121.

34. Vieira, L. M.; Números Sobre o Manganês Brasileiro. Rio de Janeiro: O Observador Econômico e Financeiro, 1949, n 161, p. 48-53; Almanaque Brasileiro Garnier, anno 1. Rio de Janeiro: Livraria Garnier, 1903, p. 155; anno 2, 1904, p. 165; anno 4, 1906, p. 179.

35. Economia Mineral do Brasil 2018. Instituto Brasileiro de Mineração, Brasília, 2018, $30 \mathrm{p}$.

36. Producção de Manganez. Retrospecto Commercial do Jornal do Commercio. Jornal do Commercio: Rio de Janeiro, 1926, p. 319.

37. Jones, T. S.; Manganese. The US Department of the Interior, Mineral Facts and Problems - 1985 Edition. Bureau of Mines Bulletin: Washington, 675, 1985, p. 484

38. Camara, A. A.; O Manganez no Estado da Bahia. Revista do Instituto Polytechnico Brazileiro, Rio de Janeiro, 1906, Tomo XXXI, pp. 17-28.

39. Burlamaque, F. L. C.; Riquezas Mineraes do Brasil. O Auxiliador da Indústria Nacional, 1850, n. 6, p. 118.

40. Lisboa, M. A. R.; Oeste de S. Paulo, sul de Mato-Grosso: geologia, industria mineral, clima, vegetação, solo agrícola, industria pastoril. Typographia do Jornal do Commercio: Rio de Janeiro, 1909.

41. O Auxiliador da Indústria Nacional, 1843, n. 1, p. 143.

42. Regulamento Sanitário de 14 de fevereiro de 1850. Relatório do ano de 1849 apresentado à Assembleia Geral Legislativa na $2^{\mathrm{a}}$ Sessão da $8^{\mathrm{a}}$ Legislatura. Tipografia Nacional: Rio de Janeiro, 1850, p. 2 (artigo $11^{\circ}$ ).

43. Elementos de Technologia-Metaes e suas aplicações, O Auxiliador da Indústria Nacional, 1883, 51, p. 198; Chimica Mineral (1) - Metaes, O Auxiliador da Indústria Nacional, 1884, 52, p. 250.

44. Notícias Industriaes, Agricolas etc. O Auxiliador da Indústria Nacional, 1861, p. 35.

45. Martins, F.; Reforma da Escola Polytechnica. O Paiz, Rio de Janeiro, 2 de julho de 1886, p. 3.

46. Actos Officiaes. Revista de Engenharia 1887, 164, 139.

47. Actos Officiaes. Revista de Engenharia 1890, 243, 243.

48. Actos Officiaes. Revista de Engenharia 1890, 248, 307.

49. Pires, F. R. M.; Cabral, A. R.; Rem: Rev. Esc. Minas 2001, 54, 205.

50. Panorama da Mineração em Minas Gerais. Instituto Brasileiro de Mineração: Brasília, 2015, p. 252.

51. O Paiz, Rio de Janeiro, 25 de setembro de 1908, p. 3.

52. O Paiz, Rio de Janeiro, $1^{\circ}$ de junho de 1901, p. 4.

53. Usina Wigg. A Imprensa, Rio de Janeiro, 3 de abril de 1899, p. 2; Sessão da Câmara dos Deputados. A Imprensa, Rio de Janeiro, 9 de dezembro de 1898 , p. 2.

54. Congresso Nacional - Annaes da Camara dos Deputados, Segunda Sessão da Terceira Legislatura, vol. VI. Imprensa Nacional: Rio de Janeiro, 1899, p. 127-131.

55. Indústria Metalúrgica. O Paiz, Rio de Janeiro, 9 de maio de 1911, p. 2.

56. A Siderurgia em Minas. O Paiz, Rio de Janeiro, 26 de fevereiro de 1910, p. 6.

57. Almanaque Brasileiro Garnier, anno 5. Livraria Garnier: Rio de Janeiro, 1907, p. 74.

58. Almanaque Brasileiro Garnier, anno 1. Livraria Garnier: Rio de Janeiro, 1903, p. 82

59. A Baixa ao Manganez e os Entraves ao Seu Commercio. Brasil Industrial, ano III, $\mathrm{n}^{\circ} 28,1919$, p. 81.

60. Manganez. Retrospecto Commercial do Jornal do Commercio. Jornal do Commercio: Rio de Janeiro, 1919, p. 65, 160

61. Jornal do Commercio do Rio de Janeiro, edição da tarde, 31 de janeiro de 1919 , p. 1.

62. Commercio Exterior do Brasil. Retrospecto Commercial do Jornal do Commercio. Jornal do Commercio: Rio de Janeiro, 1919, Annexo N. 2.

63. Indústria Siderúrgica. O Paiz, Rio de Janeiro, 30 de dezembro de 1917 , p. 9. 
64. A Prohibição da Exportação de Ouro. Retrospecto Commercial do Jornal do Commercio. Jornal do Commercio: Rio de Janeiro, 1938, p. 34.

65. Manganez. Introdução ao Relatório do Ministério da Agricultura, Indústria e Comércio em 1923. Rio de Janeiro: Imprensa Nacional, 1926, p. 92, 216.

66. Produção Mineral do Brasil. Retrospecto Commercial do Jornal do Commercio. Jornal do Commercio: Rio de Janeiro, 1940, p. 34.

67. O Manganez. O Paiz, Rio de Janeiro, 7 de setembro de 1918, p. 6.

68. Jornal do Commercio do Rio de Janeiro, edição da tarde, 11 de fevereiro de 1922 , p. 1.

69. Relatório Apresentado ao Presidente da República dos Estados Unidos do Brasil pelo Ministro de Estado da Agricultura, Indústria e Comércio - anno de 1926. Imprensa Nacional: Rio de Janeiro, 1928, p. 205.

70. Relatório Apresentado ao Presidente da República dos Estados Unidos do Brasil pelo Ministro de Estado da Agricultura, Indústria e Comércio - anno de 1927. Imprensa Nacional: Rio de Janeiro, 1929, p. 67.

71. Garimpeiros e Faiscadores do Brasil. A Noite, Rio de Janeiro, 28 de novembro de 1930, p. 2.

72. A Exportação de Minérios de Manganez-quadro demonstrativo de seu decréscimo nestes últimos 5 anos. Retrospecto Commercial do Jornal do Commercio, vol. LXI. Jornal do Commercio: Rio de Janeiro, 1934, p. 205.

73. Exportação de Minérios de Ferro. Jornal do Commercio do Rio de Janeiro, 16 de janeiro de 1938, p. 6.

74. Vieira, L. M.; Manganês do Amapá. Rio de Janeiro: O Observador Econômico e Financeiro, 1947, nº 132, p. 113.

75. As nossas exportações de manganês. Jornal do Commercio do Rio de Janeiro, 13 de maio de 1935, p. 4; Manganez. Jornal do Commercio do Rio de Janeiro, 22 de agosto de 1937, p. 8.
76. Barros, G.; Estud. Econ. 2015, 45, 153.

77. Barzaghi, L.; An. Assoc. Quim. Bras. 1943, 2, 187; Barzaghi, L.; An. Assoc. Quim. Bras. 1944, 3, 142.

78. Aumüller, A.; Rev. Quim. Ind. 1941, 112, 12.

79. Análise de Minérios de Manganês. Rev. Quim. Ind. 1941, 105, 14.

80. Meditsch, J. O.; Rev. Quim. Ind. 1959, 330, 17.

81. Ramos, M. Y. E.; Guerreiro, A.; An. Assoc. Quim. Brasil 1950 9, 61.

82. Morais, L. J; Rev. Quim. Ind. 1948, 194, 21; O Jornal do Rio de Janeiro, 11 de julho de 1948, p. 1 e 7.

83. Historia do Aproveitamento das Jazidas de Manganês da Serra do Navio, vol. I. Indústria e Comércio de Minérios S. A., 1983, 227 p.

84. Van Dorr II, J.; Park Jr., C. F.; Paivas, G.; Depósito de Manganês do Distrito da Serra do Navio, Território Federal do Amapá. Departamento Nacional da Produção Mineral, Divisão de Fomento da Produção Mineral: Rio de Janeiro, Boletim 85, 1950, 80 p.

85. Leinz, V.; An. Acad. Bras. Ciênc. 1948, 20, 211.

86. Resumo das Sessões; An. Acad. Bras. Ciênc. 1955, 27, XXVII.

87. Passos, D. S.; XII Congresso Brasileiro de História Econômica \& $13^{a}$ Conferência Internacional de História de Empresas. Niterói: Associação Brasileira de Pesquisadores em História Econômica, 2017.

88. Monteiro, M. A.; Novos Cadernos NAEA 2003, 6, n. 2, 113.

89. Barcaça para transportar o minério. A Noite, Rio de Janeiro, 4 de julho de 1949, p. 11.

90. Histórico da produção do Brasil no cenário mundial de produtos minerais. Instituto Brasileiro de Mineração: Brasília, 2013.

91. Scarpelli, W.; Novos Cadernos NAEA 2003, 6, n. 1, 101.

92. Pereira, S. F. P.; Oliveira, G. R. F.; Oliveira, J. S.; Silva, J.; Sousa Jr., P. M.; Acta Amazonica 2009, 39, 953.

93. Drummond, J. A.; II Encontro Nacional da Associação Nacional de Pós-Graduação e Pesquisa em Ambiente e Sociedade, Indaiatuba, 2004. 